Northwestern University School of Law

Northwestern University School of Law Scholarly Commons

Faculty Working Papers

2010

\title{
The Relation of the Individual to the State in the Era of Human Rights
}

Anthony D'Amato

Northwestern University School of Law, a-damato@law.northwestern.edu

\section{Repository Citation}

D'Amato, Anthony, "The Relation of the Individual to the State in the Era of Human Rights" (2010). Faculty Working Papers. Paper 99. http://scholarlycommons.law.northwestern.edu/facultyworkingpapers/99 


\title{
The Relation of the Individual to the State in the Era of Human Rights, by Anthony D'Amato*, 24 Texas International Law Journal 1-12 (1989)
}

\begin{abstract}
I address the question of the relation of the individual to the state and, in so doing, invoke Hegel, the preeminent philosopher of relationships. As students of international law, we should look forward to achieving the complex synthesis implicit in Hegel's philosophy: to promote the human rights of all persons in the natural context of the unique nation in which they live. Examines a legal problem that highlights this interrelatedness: Frolova v. Union of Soviet Socialist Republics.
\end{abstract}

Tags: International Human Rights, Hegel, Legal Norms, Nationality Relationship (Concept), Frolova v. Union of Soviet Socialist Republics

[pg1]** I would like to address the question of the relation of the individual to the state and, in so doing, invoke Hegel, the preeminent philosopher of relationships. Hegel believed that relationships are real and that everything else is a mere consequence of relationships. A few years ago, a legal problem confronted me that highlighted this interrelatedness that Hegel envisioned. I received a call from a former student that her friend, Lois Frolova, needed advice regarding a press conference she wanted to hold. Lois, an American, was going to announce a hunger strike that she was committed to endure to the death, if necessary, unless the Soviet Union allowed her Soviet husband, Andrei Frolov, to emigrate from Moscow and join Lois in Chicago. Andrei and three other "divided spouses" had also recently announced their hunger strikes from an apartment in Moscow, and this announcement had been widely reported in the press.

In examining this case, there are several relevant relationships to keep in mind. First is the basic spousal relationship between Lois and Andrei. Next are Lois's relationship with her country of nationality, the United States, and Andrei's relationship with his country of nationality, the Soviet Union. Finally, there is the relationship between the two countries. There are other interesting relationships, such as the attorney-client relationship between Lois and myself, but as you will see as we get into this case, the most interesting and complex relationship turns out to be that between Lois and the United States.

The press conference was held the next morning at Northwestern Law School. The reporters were taken by Lois's obvious dedication and sincerity, and a major "divided families" event was launched.

[pg2] The next day Lois came to my office, and before we got down to serious business I asked her how her parents reacted to the hunger strike. Her father's reaction was that of a philosophical absolutist: " Are you out of your mind? Do you think you can change the policy of the Soviet Union by threatening suicide? Do you think I've spent twenty years raising you so that you could come to an end like this for some crazy Russian in Moscow who wants to get out of his country?" Her mother's reaction, on the other hand, could be characterized as philosophical pragmatism: "Lois, if you must go on a hunger strike, then you must go on a hunger strike. Just be sure to get a little something to eat.' 
Lois then asked me for my estimate of her chances for success, and I was pessimistic. While I was concerned for the couple's health, I felt that Lois's actions and the consequent publicity [FN1] would ensure Andrei's personal safety; the Soviet Union probably would not arrest or hurt him in full view of the American public. Lois asked if there was anything else she could do, and I said that we could explore the matter further if she wanted me to represent her. We agreed upon an attorney-client relationship, [FN2] and I said, "You do have legal rights. International law clearly states that any person has the right to leave his country for any reason. [FN3] And on top of that, there is a growing body of international human rights law regarding family reunification. [FN4] Lois was a bright graduate student [FN5] and asked the right question, "But is there any way to back up these rights in a court?"

"Maybe we can sue the Soviet Union directly," I said.

"I didn't know one could sue the Soviet Union in an international court." "You're right as far as that's concerned. Not only isn't the Soviet Union a party to the International Court of Justice, [FN6] but even if it were, only states can be plaintiffs in that court, and not individual persons. [FN7]

"Then what?"

"A federal court here in Chicago might be a possibility. But the real problem is that we couldn't even get the case started without serving the Soviet Union, and [pg3] they would have sixty days to answer service of process. [FN8] Lois confirmed that no one could hold out on a hunger strike that long.

After Lois left my office, I researched the possibility of an injunction and discussed general strategy with my colleague Steven Lubet and a practicing attorney, Luis Kutner. A suit for an injunction can be commenced without formal service of process; if time is of the essence, simple notification will suffice.[FN9] We could limit the injunction to Chicago, asking the court to bar all Soviet sales of gold and purchases of wheat on the Chicago commodities markets until Andrei was given permission to emigrate.

We marshaled numerous treaties and other international instruments in support of the injunction, including the United Nations Charter, [FN10] the Universal Declaration of Human Rights [FN11] and the Helsinki Accords. [FN12] I also included provisions of the Soviet Constitution that recognize the central importance of the family.[FN13] We sent a telegram to the Soviet embassy in Washington, D.C., notifying the Soviet officials that a motion had been filed in federal court for a temporary restraining order prohibiting Soviet sales of gold and purchases of wheat on the Chicago commodities markets. I was unsure, however, whether this would galvanize the embassy into action. The officials might simply ignore the telegram. Or, more likely, the Soviet government would request the United States to intervene and ask the district judge to dismiss the motion. The Department of State and the Department of Justice have been quite active in recent years in intervening on behalf of foreign sovereigns to oppose American plaintiffs bringing human rights actions in United States courts. [FN14] 
Our twin goals of bringing home the importance of the injunction to the Soviet Union and keeping the United States government from intervening on behalf of the Soviet Union could possibly be accomplished if the United States could be joined as a co-plaintiff in the litigation against the Soviet Union. The problem, however, was that the United States government could certainly not be induced to join Lois on her side of the lawsuit. So we resorted to a little-known rule of federal civil procedure [FN15] to bring the United States in as a necessary co-plaintiff and, accordingly, served the United States with a copy of the complaint listing the United States as co-plaintiff.

But the critical strategies in the case had much more to do with relationships than with marshaling legal authority and procedure. We joined the United States as a party because of the conception of the nationality relationship under classical [pg4] international law: an individual lacks standing to sue a state under traditional theory and, hence, when an individual has a grievance against a foreign state, only the individual's state of nationality can bring the claim. [FN16] Under this view, the United States could "espouse" the claim of its national, Lois Frolova, against the Soviet Union. If the United States chose not to espouse Lois's claim, under traditional international law-and perhaps under more modern conceptions as well-there was no international norm that would compel it to do so. Nationality is thus a necessary, but not a sufficient, condition of the "espousal" doctrine. On this point, I turned to United States law. I argued that Lois had a due process right under the United States Constitution to compel the United States to assert and attempt to vindicate her international human right to live with her husband.

This piece of litigation strategy appeared to produce the desired effect. First, we had started a lawsuit between the two countries in a Chicago court, and that in itself was sure to bring Lois and Andrei's plight to the attention of the leadership in Moscow. Second, by placing the Soviet Union and the United States on opposite sides of a lawsuit that neither nation wanted, we hoped that a diplomatic conversation would ensue between the two countries in which we could expect the United States to suggest that the best way out of the mess would be for the Soviet Union simply to let Andrei emigrate. Third, the United States, suddenly faced with a novel set of questions under the necessary co-plaintiff procedure, was diverted from intervening on behalf of the Soviet Union by being forced to expend its legal energies on resisting our attempt to bring it into the case as a co-plaintiff. The net result was that the United States was not a threat to Lois's case for a few days - and, considering the hunger strike, a few days were all that we had. [FN17]

Only five days after our telegram was delivered to the Soviet embassy in Washington, the Soviet secret police visited Andrei Frolov in Moscow and told him that he could leave the country. [FN18] Since we had received corroboration through a reporter for the Chicago Tribune that Andrei would not meet with any bureaucratic obstacles in getting out of the Soviet Union, the United States role as a necessary co-plaintiff arguably was over. Indeed, if Lois later decided to pursue the case against the Soviet Union for monetary damages, having the United States involved in the case on her side might be awkward. Under classical international law theory, any monetary damages would be paid to the nation espousing its national's claim and not to the individual. In such a situation, Lois might be stuck with the additional problem of suing the United States to retrieve any damages paid by the Soviet Union to the United States. 
So when the attorney [pg5] for the Department of Justice showed up in court to argue its motion for dismissal as a co-plaintiff, I simply informed the court that I consented. [FN19]

It took Andrei Frolov almost a month to get all of his exit papers in order, but he duly arrived in the United States. The Chicago Tribune headlined the event "From Russia with Love."

I was criticized in some quarters for using manipulative legal tactics against the Soviet Union, both in asking for an injunction and in joining the United States as a necessary coplaintiff. Some thought it was frivolous [FN20] to play on the Soviets' lack of knowledge of American courts and their consequent fear that I might possibly get an injunction against their gold sales and wheat purchases. I think that those who say it was a manipulation of the legal system are implicitly adopting the perspective that nations are the entities of primary concern and that law is meant to serve national interests. My own perspective is quite different; I believe that what counts are the rights of human beings and the primacy of the individual human personality. If there were no nations in the world, Lois and Andrei would naturally have the right to live together in the place of their choosing. We may superimpose national borders on the world, but I don't see how that changes their basic right. Nations themselves, although only recently, have conceded that any person has the right to emigrate from his country and that a married couple has the right to live together in any country they choose. I see nothing wrong in deconstructing a legal system to the extent that it places and maintains barriers between a husband and wife who want to live together. On the contrary, I would argue that those who feel that I manipulated the legal system to help Lois and Andrei have themselves been manipulated by the legal superstructure into believing that people are subordinate to abstractions.

Hegel believed that persons create legal norms as rules for their interactions with other persons. Unlike the legal positivists [FN21] who see law as emanating from the legislature at the top and commanding individuals at the bottom, Hegel saw law arising from the bottom, out of the everyday interactions of persons. In this way, persons continuously fill and refill the world with the rights they have created. [FN22] Persons can be expected to obey a legal norm only if they have participated in the process of creating that norm. This notion indeed seems strange to most lawyers who deal with national legal systems, but it is familiar as a description of customary law to those who study international law.

[pg6] What are the roles of legislatures and courts in Hegel's philosophy? To Hegel, legislation is external to the lawmaking process; it is a kind of intrusion into that process, and the legislator is an outsider commanding you to do that which mayor may not be in your interest or in the interest of persons with whom you interact.

Courts, for Hegel, are subordinate and incidental to human interaction. [FN23] Courts simply recognize norms that people have created. A judicial precedent is, therefore, not itself a source of law, but rather a way of recognizing the rule-creating and rule-articulating effect of previous personal interactions. Even when a court cites a rule in its opinion, the rule is not law but rather a way of describing the law. 
Jeremy Bentham's positivism, on the other hand, is the antithesis of Hegel's view. [FN24] Bentham was an enthusiastic supporter of overactive legislatures, indeed of comprehensive civil codes. He wanted written rules to govern every aspect of your life. As Arthur Jacobson has noted, positivism effectively strives to eliminate personality from the law. [FN25] Positivism treats us as the objects of legislative commands rather than as the sources of law, and hence dehumanizes us by subjecting us to a sort of dictatorship of external law. FN26] And positivism is the reigning notion of law in the world today. It is at the root of the philosophies of those who want to "protect" legal systems against the human rights claims of individuals who challenge the structure of a given system.

A healthy dose of the study of international law is a good antidote to this prevailing positivist vision. International customary law develops from the bottom up. Through their interactions, nations both create and enforce the evolving norms of custom. [FN27] Yet the analogy between international customary law and Hegel's view of law is too easy; simply substituting "nation" for "person" in Hegel's philosophy leads to the reification of nations. Although Hegel himself was on occasion guilty of such a substitution, and although he has been thought of as the philosopher whose personification of the state was a precursor of Nazism, [FN28] I want to make the harder argument that the personification of the state is an outgrowth of Bentham's, not of Hegel's, philosophy. It was Jeremy Bentham who in 1789 helped fashion the term "international law" to mean what it does today. [FN29] It was Bentham who looked upon the state as a legal and juristic institution, and it was his positivist view that assumed international law to be [pg7] about the rights and duties of states per se, and not about the rights and duties of individuals. [FN30] Accordingly, I shall argue that, despite those aspects of Hegel's philosophy that have led some interpreters to say he apotheosized the state, a closer look at Hegel's philosophy reveals a more subtle and complex picture.

Let us consider three possible ways of looking at a state (Hegel was fond of trichotomies); transparent, translucent, and opaque. These words are, of course, very ordinary and no special significance should be attached to them. [FN31] A state is opaque under the view that I have attributed to Jeremy Bentham. [FN32] In his philosophy, the state has standing in international law and Lois is not recognized at all; we would see only the United States and could not look through it to see Lois. In Lois's case, it would be not her but the United States that was damaged by the Soviet Union's violation of international law in refusing to let Andrei Frolov emigrate. Hence, if the United States were to have sued the Soviet Union and won, international law would not require that the United States pay to Lois any monetary damages that it might have collected as a result of the lawsuit.

Many advocates of international human rights, on the other hand, view the state as utterly transparent, believing that the state is a completely artificial construct; it really does not exist in any meaningful sense. [FN33] The only thing of significance in the world is people. People have problems. People can be hurt. People have rights. Any claim that states have separate rights puts a mask on the rights of people within those states and is apt to divert our attention from the legitimate rights of persons.

I believe that neither of these polar views is consistent with Hegel's philosophy. While 
I am not sure that he would have liked the term, I think Hegel's view of the state is that it is in some sense translucent. The people in the state do not constitute and cannot claim the totality of the rights in the state; this is partly because the state also incorporates rights of people who have lived in the past and people who will live in the future, and partly because the mere sum of the individuals in the state does not fully account for the way those people behave. To some extent, people behave as they do because of the state's particular configuration. As Hegel said,

The State, its laws, its arrangements, constitute the rights of its members; its natural features, its mountains, air, and waters, are their country, their fatherland, their outward material property; the history of this State, their deeds; what their ancestors have produced, belongs to them and lives in their memory. All is their possession, just as they are possessed by it; for it constitutes their existence, their being. [FN34]

[pg8] In prosaic terms, the state is more than the sum of its parts. In representing the individuals within it, the state is in a sense effectuating their moral position in the international community. Their moral position, in turn, is not the sum of the moral positions of the individuals in the state, but rather what those persons, their ancestors, and their future generations ought to desire and have a right to desire. In a sense the state is the physical manifestation of the collective rights of the people who have lived in it, who are living in it, and who will be born within its territory.

There is a danger that this translucent view of the state can lead to nationalism and national chauvinism. Governments and leaders may be quick to suggest that they know better than the people what is in the interest of the state, [FN35] and they can rally the people behind them by engaging in adventures abroad. But while the Hegelian position can lead to nationalism, it does not necessarily point in that direction; especially if we consider the Hegelian view in the context of international law, we find that it suggests some interesting and not intuitively obvious legal positions.

Of the many examples I could choose, let me pick three cases of United States military intervention: Vietnam, Grenada, and Nicaragua. The United States went into Vietnam to fill the power gap left after the French withdrew from Indo-China following their defeat at Dien Bien Phu in 1954. The United States's avowed purpose was to prevent the spread of communism. The realization of this goal, however, required supporting the corrupt slumlords of Saigon in their fight against the indigenous revolutionary movement of the Viet Congo The result was the longest war in United States history, and one that we eventually lost. In the aftermath of our withdrawal, the massive genocide in Cambodia took thousands of lives.

Quite different was our intervention in Grenada. A military group had machine-gunned its way into control, killing the leaders of the democratic government. The United States intervened, restored the democratic government, and then withdrew.

The Nicaraguan intervention was similar in some respects to both of these cases and dissimilar in others. At first, the United States applauded the ascension to power of the Sandinista government, but as it showed signs of becoming a leftist political dictatorship (suppressing opposition newspapers and rigging elections, among other things), the United 
States shifted its support to the Contras. But the Contras did not represent a democratic movement; not only did they lack [pg9] indigenous support, they also tortured and murdered defenseless Nicaraguan citizens. Support for the Reagan administration's Nicaraguan policy waned when the American public became aware of the brutal human rights violations by the Contras.

In analyzing these three cases, we should begin with the obvious but often unnoticed proposition that in none of the interventions was annexation a goal of the United States. [FN36] This in itself is historically remarkable. Up through the nineteenth century, a vastly superior military power that intervened in a foreign country was almost certain to annex it and transform it either into a colony or a protectorate. To be sure, our foreign policy purpose might have been akin to the nineteenth century notion of "balance of power" politics. [FN37] Many political and military thinkers have indeed conceived of our foreign policy in these terms. [FN38] But this can only be rhetoric designed for domestic public relations, for in our overstock-piled nuclear age, when we can destroy any foreign country by pressing buttons, neither the United States nor the Soviet Union has any strategic military need for third-world allies, nor any need to redress insignificant imbalances among other nations.

Ultimately, the United States respected the nationhood of Vietnam, Grenada, and Nicaragua by not trying to impose upon them permanently its political control. But how should we assess the United States posture toward these countries in terms of opacity, translucency, and transparency? The Vietnam situation was one in which the United States regarded Vietnam as opaque. The United States considered the Saigon military dictatorship to be the sole legal voice of the state and refused to concern itself with the "democratic" aspirations of the people of that unfortunate country. A position based on the notion of the translucent state would have dictated that, if we had to intervene at all —and whether or not we should have is not a question that I am addressing here-we should have helped the Viet Cong establish a democratic, even if leftist, government to correspond with the wishes of the Vietnamese people. [FN39]

Grenada was, I believe, a paradigm of the Hegelian translucent position. The United States intervened on behalf of the Grenadians who otherwise would have [pg10] been at the mercy of the small group of murderers who usurped power. After restoring the democratic structure of the state, United States military forces left. [FN40] The United States position might be characterized as supporting the nation of Grenada for the people of Grenada to enjoy, and opposing the capture of that nation by a group of thugs who would have established an authoritarian dictatorship against the wishes of the people.

This brings me to the most difficult case-Nicaragua. If the new Sandinista government were going to do the same thing as the thugs who temporarily took over Grenada, but over a few years' time, then I think the United States would have a prima facie case for intervening on behalf of the people of Nicaragua. Moreover, the time for intervention in such cases must be before the new government has consolidated its power, destroyed opposing political parties, abolished elections, and put opposition newspapers out of business. Intervention on behalf of the people of Nicaragua against the gradual movement toward totalitarianism of the new government was, therefore, a policy that had to be set in motion before all the evidence was in about the intentions of the new government. 
But the problem in Nicaragua was that the United States could not find an opposition movement that represented the wishes of the people. The Contras, whom the United States government backed, were led by deposed officers of the previous Somoza dictatorship; Unlike Castro, who in his guerilla campaign in the hills of Cuba enjoyed the overwhelming support of the villagers, the Contras in Nicaragua have never had such indigenous support and have turned instead to the arbitrary murder and torture of the citizenry in order to "prove" to them that the existing government is powerless to protect its people and that, therefore, they should support the Contras. Few citizens have been won over by these desperate tactics.

The failure to find an indigenous movement antithetical to the Sandinista government should have signaled to the Reagan administration that the Sandinistas indeed had popular support, and that perhaps it was United States support of the Contras rather than widespread domestic resistance to the new government that was pushing the Sandinistas toward suppression of civil liberties. (In any dangerous military situation, any government, including democratic governments, will curtail the freedoms of the citizenry.)

Some highly traditionalist writers on international law would agree that the United States should not have supported the Contras or mined Nicaragua's harbors, but for the reason that no transboundary use of military force is acceptable. Their position is echoed by many leaders of third-world nations who proclaim publicly that under no circumstances should the superpowers intervene in the internal affairs of any nation. These officials take an opaque view of nations as entities on the international scene and cite article 2(4) to back their position. But I think we should regard their position as self-serving. Obviously, these [pg11] third-world leaders want to be secure in their home countries against all external intervention, especially the kind that would establish a democratic government and maybe remove them from office in the process. These leaders do not necessarily represent the legitimate aspirations of their people.

Furthermore, I think we should always be skeptical about any legal argument that categorically prohibits the use of force, because some uses of force are clearly required in order to protect people against brutality and degradation. If you are walking down a street and someone assaults you, you would expect a nearby police officer to intervene on your behalf. You would expect the police officer to use force if necessary. Or consider a case that is more closely analogous to a nation: Suppose you walk by a house and see through the window a man savagely beating a woman. Even if they are husband and wife, and even if they are in their own house and on private property, you would have a moral obligation to call the police and would expect the police to intervene. If the police were not available, you would have a moral right to intervene personally. Why should the situation in the house be any different from the situation within a nation? If the government kidnaps or "disappears" citizens, and continues to do so as a policy, why should that government be immune from outside military intervention? Such a government has no moral claim to be left alone to work its arbitrary will upon the people.

Certainly, if there were a multilateral police force operant in the world today, that force - and not any individual nation acting unilaterally — would be the proper agent to engage in these humanitarian interventions. But there is no such force. In its absence, nations do engage from time to time in humanitarian intervention, [FN41] and I suggest that the 
intervention is legal under international law if the use of military force itself is not expected to cause greater suffering or loss of life than that caused by those violations of human rights that it is attempting to remedy.

In short, what goes on in another country should no longer be obscured by an opaque view of the state. International morality, in the form of humanitarian intervention, has caught up with international law. Of course, intervention cannot end in annexation or colonization and must be terminated when the evil has been remedied, but the practice of states is now telling us that, within these parameters, governments are no longer insulated from the international legal community if they brutalize their own citizenry. In other words, states should be thought of as translucent entities.

Returning to Lois Frolova's case, I would have preferred to see the United States welcome, not fight, the opportunity to join us as co-plaintiff. But the United States is still a long way from supporting the private enforcement of international human rights, even in its own courts. Rather, the government prefers to monopolize all foreign affairs matters and settle them, if at all, on a political basis. Unfortunately, the notion of deregulation and smaller government, [pg12] although embraced domestically, is far from being actualized in the conduct of United States foreign policy. [FN42]

Looking ahead, I hope that the new and exciting human rights cases that some American lawyers are initiating in United States courts will help educate our own government as to the proper translucency of our own country .Our government should make every effort to assist its citizens in the assertion of their international human rights. These assertions should become part of what this country stands for. Foreign policy should not be decided solely in Washington, D.C., but rather should be an expression of the legitimate aspirations of all the people, as at least some of these aspirations are articulated in our own court system. And we should welcome, not resist, similar human rights cases being filed in the courts of other nations. Courts throughout the world can be a forum in which people can assert the primacy of their human rights, in all situations in which states are impeding the realization of those rights. The United States should welcome this trend and not, by adherence to a principle of the opacity of a state, resist it on the grounds of, 'sovereignty.'

If we reject the state as either opaque or transparent, we are rejecting simplistic approaches and embarking instead on a new vision, albeit one of great complexity. The rules of international law will not seem nearly as clear as they were in the past. The intellectual challenge to students who want to begin a career in international law will be much greater than it was to past generations. But as students of international law, we should look forward to achieving the complex synthesis implicit in Hegel's philosophy: to promote the human rights of all persons in the natural context of the unique nation in which they live.

\section{Footnotes}

*Copyright 1988, Anthony D'Amato. 
This is an edited version of an address given at the Texas International Law Journal Association's 1988 Annual Banquet upon the author's receipt of the Carl H. Fulda Award for outstanding achievement in the field of international law. The Award is given in honor of Carl H. Fulda, former holder of the Hugh Lamar Stone Chair in Civil Law at the University of Texas School of Law.

J.D., Harvard Law School, 1961; Ph.D., Columbia University, 1968. Professor D'Amato is the Chairman of the Inter-Bar Study Group on Independence of Lawyers and Judges and a Council Member of the American Bar Association's Section of International Law. Professor D'Amato is also a member of the Board of Editors of the American Journal of International Law.

**Numbers in the format “pg1” etc. refer to the pagination of the original publication.

[FN1] The Chicago coverage soon was picked up nationally, and in a few days Lois was on ABC's Nightline program. Nightline (ABC television broadcast, May 17, 1982).

[FN2]. The arrangement was on a pro bono basis, with Lois paying out-of-pocket expenses and court filing fees.

[FN3] Universal Declaration of Human Rights, art. 13(1), (2), GA Res. 217, 3 U.N. GAOR at 71, U.N. Doc. A/810 (1948); International Covenant on Civil and Political Rights, art. 12, G.A. Res. 2200, 21 U.N. GAOR Supp. (No.16) at 52-58, U.N. Doc. A/6316 (1966).

[FN4] Conference on Security and Cooperation in Europe, Final Act [hereinafter Helsinki Accords], 73 DEPT. ST. BuLL. 323 (1975), reprinted in 14 I.L.M. 1293 (1975).

[FN5] She later received her Ph.D. from Stanford; her thesis was on nineteenth century Russian liberalism.

[FN6]. The U.S.S.R. has not consented to compulsory jurisdiction under article 36(2) of the Statute of the International Court of Justice. 1983-1985 I.C.J.Y.B. I, 38-42, 46 (1985).

[FN7] Statute of the International Court of Justice, June 26,1945, art.34, para. 1, 59 Stat. 1055,T. S. No.993. It would have been superfluous to tell Lois that, in theory, the United States could espouse her claim and bring an action in the International Court of Justice. See infra text accompanying note 16 . Not only would it take months to bring the argument before the State Department, but there would be practically no chance that the State Department could be convinced.

[FN8] 28 U.S.C. § 1608(d) (1982).

[FN9] FED. R. CIV. P. 65(a)(1).

[FN10] U.N. CHARTER arts. 55-56.

[FN11] G.A. Res. 217, 3 U.N. GAOR at 71, U.N. Doc. A/810 (1948). 
[FN12] Helsinki Accords, supra note 4, at 340.

[FN13] See, e.g., KONSTITUTSIYA SSSR [KONST. SSSR] arts. 35, 53 (USSR), translated in 17 A. Blaustein \& G. Flanz, Constitutions of the Countries of The World 26, 29 (1972).

[FN14] See, e.g., Republic of the Philippines v. Marcos, 806 F.2d 344 (2d Cir. 1986), cert. denied, 107 S. Ct. 2178 (1987); Siderman v. Republic of Argentina, No.82-1772, slip op. (C.D. Cal. Sept. 28, 1984).

[FN15] FED. R. CIV. P. 19(a).

[FN16] See R. WALLACE, INTERNATIONAL LAW 65, 175-94 (1986).

[FN17] As an aside, the publicity finally penetrated all the way to the dean's office of Northwestern Law School. Dean David Ruder stopped me in the hall and asked, "What's this about a hunger strike that somebody is conducting in your office?" He must have thought that it was a kind of sit-in or other illegal activity. I replied that Lois Frolova, my client, was conducting a hunger strike wherever she went, and that included my office. I said with a smile that the hunger strike had little choice but to follow her around.

[FN18] He was the only one of the four hunger strikers in the Moscow apartment who was allowed to leave. Two of the others eventually abandoned their strike, and a third was hospitalized.

[FN19] The eventual lawsuit for damages was dismissed in district court on the act of state doctrine, and the dismissal was affirmed in the court of appeals on entirely different grounds (sovereign immunity). Frolova v. Union of Soviet Socialist Republics, 558 F. Supp. 358 (N.D. Ill. 1983), affd, 761 F.2d 370 (7th Cir. 1985).

[FN20] Oliver, Book Review, 81 AM. J. INT'L L. 445, 446 (1987); see also Letter from Burns H. Weston and Clarification by Covey T. Oliver, reprinted in 81 AM. J. INT'L L. 635-37 (1987).

[FN21] Legal positivism is the belief that the validity of law is not affected by moral or ethical values; morals do not enter into the definition of law. 4 THE ENCYCLOPEDIA OF PhILOSOPHY 418-20 (1972); D'Amato, The Moral Dilemma of Positivism, 20 VAL. U .L. ReV. 43 (1985).

[FN22] A. Jacobson, Hegel's Legal Plenum, 10 CARDOzo L. REV. 877 (1988-1989)

[FN23]. T. KNOX, HEGEL'S PHILOSOPHY OF Right 141 (1942).

[FN24] One writer summarized Bentham's view as follows: "Rights proceed from laws, and laws from government: men living without government live without rights." E. KAYSER, THE GRAND SOCIAL ENTERPRISE 38 (1932).

[FN25] A. Jacobson, supra note 22, at 13-14. 
[FN26] See J. Bentham, An InTROduction to the Principles of Morals ANd Legislation 8-9 (J. Burns \& L. Hart eds. 1970).

[FN27] I considered at some length the creational aspect of international customary law in A. D'AMATO, THE CONCEPT OF CUSTOM In INTERNATIONAL LAW 104-66 (1971), and the enforcement aspect in A. D'AmATo, InTERnATIONAL LAW: Process AND PROSPECT 27-55 (1987); see also Janis, Jeremy Bentham and the Fashioning of International Law, 78 AM. J. INT'L L. 405, 409 (1984).

[FN28] K. Popper, The Open Society AND Its EnEMIES 226-73 (1950).

[FN29] See J. BENTHAM, supra note 26, at 297-98; Janis, supra note 27, at 405.

[FN30] Janis, supra note 27, at 409.

[FN31] Indeed, I choose them because they do not come to us already weighted with significance. Other writers have used terms such as "transnationalism," "realism," "utopianism," and "cosmopolitanism," but I think these terms are less successful in conveying accuracy of meaning. See, e.g., T. NARdin, LAW, Morality, And the Relations Of States 98, 101-02 (1983).

[FN32] The Benthamite view was translated most thoroughly into international law by the supremely influential treatise of Lassa Oppenheim. L. OPPENHEIM, INTERNATIONAL LAW (8th ed. 1955).

[FN33] See Elfstrom, On Dilemmas Of Intervention, 93 ETHICs 709, 713 (1983).

[FN34] G.W.F. Hegel, InTROduction to the PhilOSOPHy OF History 406 (Loewenberg ed. 1929) (emphasis in original).

[FN35] Rousseau, for example, considered this view carefully. J.-J. RousSEAU, THE SOCIAL CONTRACT 131-34 (M. Cranston trans. 1968). On a superficial reading, Rousseau's "general will" can be that which is asserted by a totalitarian government and ratified by overwhelming plebiscite; we are familiar with the uses to which Hitler and Mussolini put this "general will." On a deeper reading, Rousseau's philosophy has to be considered in light of the great international lawyers, especially Grotius and Pufendorf, whom he had read and to whom he was reacting. Rousseau's "general will" turns out to reflect natural law, which (in his theory) is not easily manipulated by charismatic leaders. What is most obviously missing from Rousseau is the element later supplied by Hegel: the configuration of the state itself as a physical manifestation of the rights (the general will in the natural-law sense) of the people

[FN36] By neither annexing nor colonizing the three nations, the United States arguably did not violate article 2(4) of the United Nations Charter, which prohibits the use of force against the territorial integrity or political independence of another country. Of course, other writers have 
looked at the language of article 2(4) and concluded the opposite. My purpose here, however, is not to engage in traditional legal analysis.

[FN37] For an informative discourse on balance of power politics, see E. STOWELL, INTERVENTION IN INTERNATIONAL LAW 414-31 (1921).

[FN38] In particular, Henry Kissinger has emphasized the Metternich approach in his many books and papers contemporary with the Vietnam intervention.

[FN39]. There is no evidence that a leftist popular revolution would necessarily lead to control by an external power such as the Soviet Union. Certainly China-for all its radical communism under Mao — remained steadfastly independent of Moscow. The lesson of China, however, may not have been perceived in the mid-1960s when the United States began escalating its military commitment in Vietnam. But even apart from these considerations, any revolutionary movement in Vietnam that reflected the aspirations of the majority of the people would by definition have to be "leftist," since the Saigon government was an extreme rightist dictatorship.

[FN40] I said at the time that I thought that, irrespective of our avowed purpose, our real purpose was humanitarian and fully consistent with international law. D'Amato, Intervention in Grenada: Right or Wrong? N.Y. Times, Oct. 30, 1983, at E18, col. 3.

[FN41]. For a collection and excellent discussion of intervention cases, see F. TESON, HUMANITARIAN INTERVENTION: AN INQUIRY INTO LAW AND MORALITY 155-200 (1987).

[FN42] See D'Amato, International Human Rights at the Close of the Twentieth Century, 22 INT'L LAW. 167 (1988). Of course, I would argue that Lois's case is not "foreign policy" at all, but rather a matter of private human rights. The United States should intervene in the lawsuit only because Lois asserted a clear human-rights claim; "political" reasons should not count either way. Moreover, it's a two-way street; we should expect, and indeed encourage, lawsuits against our country in Soviet courts by Soviet citizens, with the Soviet government intervening on their behalf. Our "protection" against such lawsuits is simply the fact that we do not, and should not, commit human-rights violations such as refusing to allow any person to leave this country to live with his or her spouse in the Soviet Union. 